\title{
Relações entre idade, porcentagem de consoantes corretas e velocidade de fala $* * *$
}

\author{
Relationship between age, percentage of consoants correct and \\ speech rate
}

Gislaine Aparecida Folha*

Cláudia Maria de Felício**

\section{*Fonoaudióloga. Mestranda da Faculdade de Medicina de Ribeirão Preto da Universidade de São Paulo. Endereço para correspondência: Rua Nioac, 515 - Apto. 11 - Ribeirão Preto - SP - CEP 15051-250 (gislaine@fmrp.usp.br). \\ **Fonoaudióloga. Doutora em Pscicobiologia pela Faculdade de Filosofia Ciências e Letras de Ribeirão Preto - Universidade de São Paulo. Professora Doutora do Curso de Fonoaudiologia da Faculdade de Medicina de Ribeirão Preto da Universidade de São Paulo. \\ ***Trabalho Realizado na Faculdade de Medicina de Ribeirão Preto da Universidade de São Paulo e na Faculdade de Odontologia de Ribeirão Preto da Universidade de São Paulo.}

Artigo Original de Pesquisa

Artigo Submetido a Avaliação por Pares

Conflito de Interesse: não

Recebido em 15.05.2008.

Revisado em 28.08.2008; 06.11.2008. Aceito para Publicação em 03.02.2009.

\begin{abstract}
Background: there is a lack of information regarding the relationship between age, speech rate and speech performance. Aim: to analyze and to compare the performance of children according to age, Percentage of Consonants Correct (PCC) and speech rate, and to determine the relationship between these variables. Method: participants of this study were two hundred children divided in three different age groups: 6:0 to 8:0 years (Group I), 8:1 to 10:0 years (Group II), and 10:1 to 12:6 years (Group III). The following tests were used: speech rate tasks, imitation and picture naming (ABFW - Language test for children) and the Percentage of Consonants Correct (PCC) was calculated. Statistical analysis was performed using ANOVA for inter-group analysis, followed by the Tukey Test. The coefficient of Pearson Correlation was used to analyze the relationship between age, speech rate and speech performance (PCC). Results: there was a significant difference between the PCC and speech rate when comparing the three groups $(\mathrm{p}<0.001)$. Regarding speech rate test, using /pataka/ as a stimulus, there were significant differences between Group I and the two other groups $(\mathrm{p}<0.01)$. There was a significant and positive correlation between age, the PCC and speech rate ( $\mathrm{p}<0.05)$. Conclusion: speech performance, measured by the PCC, and speech rate increased according to age, resulting in significant differences between the three age groups. The increase of the PCC indexes and of speech rate were directly proportional.
\end{abstract}

Key Words: Face; Speech; Motor Skills; Task Performance and Analysis; Speech Production Measurement; Child Development.

\section{Resumo}

Tema: faltam informações a respeito da relação entre idade, velocidade de fala e desempenho na fala. Objetivo: analisar e comparar o desempenho de crianças, de acordo com a faixa etária, quanto ao índice de porcentagem de consoantes corretas (PCC) e medidas de velocidade de fala, bem como determinar a relação entre essas variáveis. Método: os participantes deste estudo foram duzentas crianças agrupadas em três faixas etárias: 6:0 a 8:0 anos (Grupo I), 8:1 a 10:0 anos (Grupo II); 10:1 a 12:6 anos (Grupo III). Foram aplicados testes de velocidade de fala, de nomeação de figuras e imitação de vocábulos (ABFW Teste de Linguagem Infantil) e calculados os índices porcentagem de consoantes corretas (PCC). A análise de variância (ANOVA) foi utilizada para a comparação do desempenho dos grupos, seguida pelo teste de Tukey. Para analisar a relação entre idade, velocidade de fala e PCC foi utilizado o teste de correlação de Pearson. Resultados: houve diferença significante entre os três grupos quanto ao PCC e a velocidade de fala $(\mathrm{p}<0,001)$. De acordo com o teste de velocidade de fala usando o estímulo /pataka/, houve diferenças significantes entre o grupo I e os outros dois grupos $(\mathrm{p}<0,01)$. Houve correlação positiva e significante entre idade, desempenho nas tarefas de PCC e velocidade de fala $(\mathrm{p}<0,05)$. Conclusão: o desempenho na fala, medido pelo PCC, e a velocidade de fala aumentaram de acordo com a faixa etária, resultando em diferenças significantes entre os grupos. O aumento do PCC e da velocidade de fala foram diretamente proporcionais.

Palavras-Chave: Fala; Destreza Motora; Análise e Desempenho de Tarefas; Medida de Produção da Fala; Desenvolvimento Infantil.

Referenciar este material como:

- Folha GA, Felício CM. Relationship between age, percentage of consoants correct and speech rate (original title: Relações entre idade, porcentagem de consoantes ב 3 corretas e velocidade de fala). Pró-Fono Revista de Atualização Científica. 2009 jan-mar;21(1):39-44. 


\section{Introduction}

Speech production involves sensory information and motor commands. Motor control develops gradually in children (1-4) and the biomechanical and neuromotor bases appear to influence the emergence of speech sounds (5).

A precise execution of sounds and sound sequences guarantees the intelligibility of speech and is the result of the precision of tonus, force, velocity, limit and stability. Thus, these aspects must be included in the assessment of the physiological support involved in the motor production of speech (6) since neuromuscular processing can be investigated on the basis of the evidence of the muscular behaviors that contribute to the normal production of speech (7-8).

In order to assess speech, speech therapists often use tests such as picture naming, imitation of words (9) and of spontaneous speech (10-11) with reference to what can be expected for each age range. Although less employed, perhaps due to the scarcity of parameters for comparison and of evidence of their relation to speech, speech rate tests can also be useful. These tests employ syllables (diadokinesis) (12-14), words and numbers (15) in order to assess the ability to produce several repetitions of relatively simple patterns of opposite contractions and provide information about the maturation, neuromotor integration (13) and development of speech skills in children (14).

The objectives of the present study were to analyze and compare the performance of children regarding percentage of consonants correct (PCC) and speech rate tasks according to age range and to determine the relation between the variables age, PCC and speech rate.

\section{Method}

The study was approved by the Human Research Ethics Committee of the Institution (HCFMRPUSP $\mathrm{n}^{\circ}$. 12277/2005). The persons responsible for the children were informed about the objectives and methods of the study and gave written consent for data collection and publication of the results.

Two-hundred consecutive children on the university waiting list for treatment at the Children's Clinic of the Dental School of Ribeirão Preto, University of São Paulo, aged 6 to 12 years and 6 months (mean age $=9$ years) were studied. The age range was defined in order to include children who were at the end of the period of acquisition and development of speech and language or in a subsequent period.

The inclusion criteria were: to be a native Brazilian Portuguese speaker, to present no specific complaint of communication, and to speak no other language.

The exclusion criteria were: to present hearing loss, mental retardation, neurological or emotional disorders and craniofacial malformations, as determined by examination of the medical records and by anamnesis.

The sample consisted of 67 children aged 6:0 to 8:0 years (Group I - GI, 32 boys and 35 girls), 68 children aged 8:1 to 10:0 years (Group II - GII, 34 boys and 34 girls), and 65 children aged 10:1 to 12:6 years (Group III - GIII, 31 boys and 34 girls).

\section{Data Collection}

Anamnesis was performed with the persons responsible for the children in order to obtain the information necessary for the study, such as identification, age and data regarding health and development.

\section{Speech Measures}

Speech samples were obtained with the help of the protocols of phonetic-phonologic evaluation of the ABFW Infantile Language Test (13), which includes the word imitation test and picture naming test.

The replies were recorded on a cassette audiotape with a Panasonic RQ-L11 Mini Cassette Recorder and transcribed according to the international phonetic alphabet. Distortion, substitution and omission of consonants were considered to be errors.

Only the consonants that the child had the intention to produce in the word were considered to be correct, whereas repetitions of syllables and incomplete or unintelligible words were discarded. The PCC rate proposed by Shireberg and Kwiatkowski (16) was then calculated as the number of consonants correctly produced divided by the sum of the number of incorrect consonants multiplied by 100 . This procedure was applied to the imitation (PCCI) and naming tests (PCCN) of each child.

\section{Speech Tarte Rate? Measures}

Six stimuli were used, three of them consisting of monosyllable word pairs, boi-pé (cow-foot in 
English) (E1), mãe-giz (mother-chalk) (E2), rio-chão (river-floor) (E3), and three consisting of pairs of three-syllable words, avião-cabeça (airplane-head) (E4), orelha-banana (ear-banana) (E5) and bolachamacaco (cookie-monkey) (E6) (15), plus the sequence /pataka/.

It was explained to the children that they should try to repeat the words and sounds spoken to them as fast as possible without making mistakes. The model was first given by the examiner using stimuli different from those to be given in the test. The child imitated the examiner and the test was then started.

The productions were recorded on a cassette audiotape with the Panasonic RQ-L11Mini Cassette Recorder and speech rate was then calculated using a digital chronometer (Cronobios).

In the case of monosyllable and three-syllable words, the first two emissions of the pair were discarded (due to possible irregularities in their emission) and the subsequent 5 emissions of the pair were analyzed. The result of the test was obtained by dividing the number of emissions of the pairs (5) by the total time spent by the child to emit them.

In the speech rate test with the word /pataka/ the repetitions were interrupted by the examiner after 3 seconds. The samples were audiorecorded and the number of complete repetitions emitted within 3 seconds was later counted (1).

The examiners were two speech therapists trained in the application and analysis of the tests employed. In order to ensure reliability of the evaluations, $20 \%$ of he samples recorded were randomly selected using the GraphPad software (Graphpad Software, Inc) and re-evaluated to determine the phonetic inventory, PCC index and speech rate measures by examiner 1 (test-retest reliability) and also by examiner 2 (inter-examiner reliability).

The test-retest reliability of examiner 1was 0.99 for the PCC index and 0.85 for speech rate. The reliability between examiners 1 and 2 was 0.89 for PCC and 0.80 for speech rate according to the splithalf reliability test.

Data analysis

The performance of the children according to age, test and stimulus was analyzed usin by analysis of variance. One-way ANOVA was used for PCC and speech rate (monosyllable and threesyllable words), with group being the independent variable and the measurements of speech in the two phonology tests (PCCI or PCCN) or the stimuli being the dependent variables, respectively. Oneway ANOVA was also used for speech rate with the /pataka/ stimulus, with age range being the test variation. The Tukey post-test was applied to determine differences between groups.

The correlations between the variables age, children's performance in speech tasks and speech rate considering the sample as a whole were calculated by the Pearson product-moment correlation test. The calculations were made using the Statistica data analysis software, with the level of significance set at 0.05 .

\section{Resultados}

Percent of consonants correct (PCC)

Analysis of variance showed significant differences between groups $\{\mathrm{F}(2,197)=10.68, \mathrm{p}=$ $0.00\}, \operatorname{task}\{\mathrm{F}(1,197)=39.35 ; \mathrm{p}<0.000\}$ and effects of group and task interaction $\{F(2,197)=6.8$; $\mathrm{p}<0.001\}$. The Tukey post hoc test revealed significant differences among the three groups $(p<0.001)$. Figure 1 presents the mean performance of the groups in each tests.

\section{Speech Rate}

Analysis of variance showed significant differences between groups $\{\mathrm{F}(2,197)=13.48, \mathrm{p}=0.00\}$ and stimuli $\{\mathrm{F}(5,985)=366.67 ; \mathrm{p}<0.000\}$ regarding speech rate with monosyllable and three-syllable words. There were significant differences among the three groups, whose mean rates (repetitions of the stimuli per second) were: $\mathrm{GI}=1.28, \mathrm{GII}=1.37, \mathrm{GIII}=$ 1.47 , with $\mathrm{p}<0.001$ between GI and GIII and $\mathrm{p}<0.05$ for the other comparisons. Figure 2 presents the mean values for the stimuli for each group.

Analysis of variance showed significant differences between groups $\{\mathrm{F}(2,197)=6.42$, $\mathrm{p}=$ $0.002\}$ in speech rate for the word /pataka/. The post hoc test revealed significant differences between GI $($ mean $=5.86)$ and GII $($ mean $=6.48)$ and between GI and GIII (mean=6.48). $(\mathrm{p}<0.01)$.

There were positive and significant correlations between age and children's performance in speech (PCCI and PCCN) and in speech rate (monosyllables, three-syllable words and /pataka/). Also, there were significant correlations between PCC and speech rate measures, except for the S5 stimulus (orelha-banana), as well as between the speech rate measures themselves. The Pearson $r$ values and the levels of significance are given in Table 1. 
FIGURE 1: Mean speech performance measured by PCCI and PCCN in each group (age range).

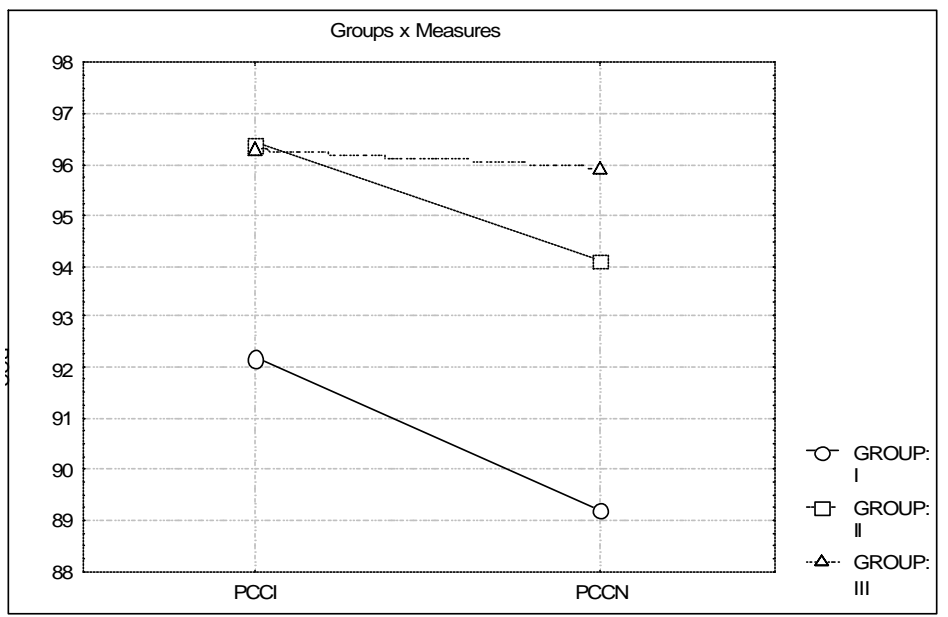

FIGURE 2: Mean speech rate (emissions per second) for each group and stimulus.

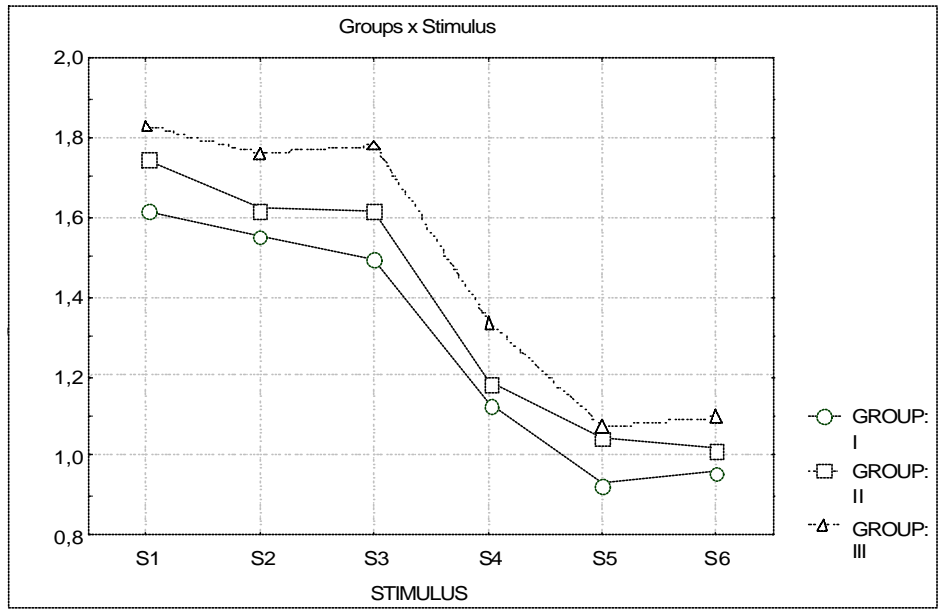

TABLE 1. Correlation coefficients between variables and level of significance

\begin{tabular}{|c|c|c|c|c|c|c|c|c|c|}
\hline & AGE & PCCI & PCCN & /pataka/ & S1 & S2 & S3 & S4 & S5 \\
\hline PCCI & $0.22^{* *}$ & & & & & & & & \\
\hline PCCN & $0.33^{* * *}$ & $0.86^{* * *}$ & & & & & & & \\
\hline /pataka/ & $0.22 * *$ & $0.23 * * *$ & $0.20 * *$ & & & & & & \\
\hline S1 & $0.23^{* * *}$ & $0.19 * *$ & $0.22^{* * * *}$ & $0.33^{* * *}$ & & & & & \\
\hline S2 & 0.27 ***⿰冫⿰亅⿱丿丶丶 & $0.21 * *$ & $0.25 * * *$ & $0.29 * * *$ & $0.34 * * *$ & & & & \\
\hline S3 & $0.28^{* * *}$ & $0.19 * *$ & $0.19 * *$ & $0.36^{* * *}$ & $0.46^{* * * *}$ & $0.58^{* * *}$ & & & \\
\hline S4 & $0.29 * * *$ & $0.14^{*}$ & $0.18 * *$ & $0.42 * * *$ & $0.33 * * *$ & $0.46^{* * *}$ & $0.52 * * *$ & & \\
\hline S5 & $0.21^{* *}$ & 0.1 & 0.12 & $0.31 * * *$ & $0.42 * * *$ & $0.39 * * *$ & $0.47 * * *$ & $0.48^{* * *}$ & \\
\hline S6 & $0.27 * * *$ & $0.17 *$ & $0.20 * *$ & $0.35^{* * *}$ & $0.35^{* * *}$ & $0.45^{* * *}$ & $0.56^{* * *}$ & $0.56^{* * *}$ & $0.57 * * *$ \\
\hline
\end{tabular}

Pearson correlation test and levels of significance $* \mathrm{p}<0.05 .{ }^{* *} \mathrm{p}<0.01 .{ }^{* * *} \mathrm{p}<0.001$. 


\section{Discussion}

The rapid, precise and coordinated synthesis of multiple lingual-buccal-vocal movements within long sequences of phonemes represents one of the most extraordinary tasks executed by the human motor system (17).

"Speech errors" are expected to occur in children during normal development. According to the linguistic model, the child use phonologic processes that reflect specific rules in order to simplify adult phonologic patterns, but that interfere little with speech intelligibility (18). From the viewpoint of motor control, the regularities of childhood phonology result in part from influences of the development of oral motor control, i.e., coordinative restraints oblige the child to generate a motor solution approaching the adult model. Thus, phonologic development can be affected by countless factors such as preexisting neuromuscular organization, previous experiences, and the spatial and temporal requirements of a given phoneme (2).

According to the objective of the present study of analyzing the performance of children aged 6 years to 12 years and 6 months in speech tasks using as a measure PCCD calculated from imitation and naming tests and speech rate, as well as the relation between variables, significant differences were detected between the three age ranges in the analysis of PCC. It was also observed that PCCI and PCCN performance was similar for GIII, whereas for GI and GII the mean PCCI values were higher than the PCCN values.

In traditional analysis of articulation, the number of correct items increases with age in children up to 7 years old (19). In the present study, the difference between GI (children aged 6:0 to 8:0 years) and the other two groups can be explained by phonologic development, whereas the difference between GII and GIII could be associated with several factors such as oral motor control, which continues to undergo a process of maturation and refinement even after the period expected for domination of the phonetic-phonologic system (1, 3-4).

The development of speech motor control requires more than biological influences. Intrinsic factors also participate in this process, such as cognitive/linguistic and sensorimotor development, as well as extrinsic factors such as hearing and visual stimulation and perceptive salience (20-21). Thus, the fact that GIII children showed similar performance in the imitation and naming tests, in contrast to the other age ranges, may reflect the effect of multiple variables.
In the analysis of speech rate (pairs of monosyllable and three-syllable words) there was a significant difference between the three age groups, i.e., the older the age range, the faster the speech rate. The rate of production of the various stimuli was also different, with the three-syllable word pairs (orelha-banana and bolacha-macaco) resulting in lower mean values, confirming previously reported results $(14,22)$.

In the speech rate test with the /pataka/ stimulus there were significant differences between the mean values of GI and those of GII and GIII, with younger children having more difficulty with this stimulus than older children (14).

The age of the children was positively correlated with speech performance (PCC) and with speech rate for the monosyllable, three-syllable and /pataka/ stimuli. Taken as a whole, the results confirm that motor control evolves to more stable movement during development (1, 3-4, 23).

The correlations between speech performance (PCC) and speech rate and between the various stimuli employed to assess speech rate were also significant. These results support the notion that the rate of movement that indicates the capacity for variation of the structures involved and their sequencialization possibilities (7) is one of the variables implicated in the precise execution of sounds and sound sequences (6).

The tests of maximum repetition rate or diadokinesis (maximum rate of repetition of syllables with point and mode variation) assess the ability to produce various repetitions of relatively simple patterns of opposite contractions and provide information about neuromotor maturation and integration (13), as well as information about the rate, precision, fluency and development of speech skills (14). In children with normal development, these skills are associated with age (24-25).

Thus, during development, motor control becomes differentiated and synchronized between structures (2). The behavior of each subunit is determined by the task and by the behavior of other subunits by means of coordinating structures that are collective functional action units (26). The articulatory strategies used during development demonstrate the influences of biomechanical and neuromotor bases on the emergence of the motor skills of speech (5). Changes in white matter density observed along the fibers that support the motor functions of speech can explain the development of certain motor skills (27) after the period of speech and language acquisition. 


\section{Conclusion}

On the basis of the present study, it was possible to conclude that oral motor control analyzed by speech rate was related to speech performance measured by PCC, with both items evolving with increasing age range, confirming the role of the process of neuromotor maturation in speech skills.
Consequently, speech development as well as speech disorders should be approached from different perspectives so that the diagnosis may define which level(s) and subsystem(s) may be altered.

Acknowledgments: Research supported in part by Conselho Nacional de Pesquisa (CNPq), Ministério da Ciência e Tecnologia do Brasil and by pela Fundação de Apoio ao Ensino, Pesquisa e Assistência do Hospital das Clínicas, Faculdade de Medicina de Ribeirão Preto, Universidade de São Paulo (FAEPA/HCRP/FMRP/USP).

\section{References}

1. Robbins J, Klee T. Clinical assessment of oropharingeal motor development in young children. J Speech Hear Disord. 1987;52(3):271-7.

2. Green JR, Moore CA, Higashikawa M, Steve RW. The physiologic development of speech motor control: lip and jaw coordenation. J Speech Lang Hear Res. 2000;43:239-55.

3. Ballard KJ, Robin DA, Woodworth G, Zimba LD. Age related changes in motor control during articulator visuomotor tracking. J Speech Lang Hear Res. 2001;44(4):763-77.

4. Munson B. Variability in /s/ production in children and adults: evidence from dynamic measures of spectral mean. J Speech Lang Hear Res. 2004;47(1):58-69.

5. Green JR, Moore CA, Reilly KJ. The sequential development of jaw and lip control of speech. J Speech Lang Hear Res. 2002;45:66-78.

6. Duffy JP. Motor speech disorders: substrates, differential diagnosis e management. St. Louis: Mosby; 1995.

7. Andrade CRF de História natural da gagueira - estudo II: sistema miofuncional oral e funções. Pró-Fono Revista de Atualização Cientóífica. 2002;14(3):361-70.

8. Barros FC, Felício CM, Ferreira CLP. Controle Motor da fala: teoria e provas de avaliação. Revista da Sociedade Brasileira de Fonoaudiologia. 2006;11(3):163-9.

9. Wertzner HF. Fonologia. In: Andrade CRF, Beffi-Lopes DM, Fernandes FDM, Wertzner HF. ABFW: Teste de Linguagem Infantil nas Áreas de Fonologia, Vocabulário, Fluência e Pragmática. Carapicuíba: Pró-Fono; 2000.

10. Hage SRV, Carvalho KG, Padovani CR, Guerreiro MM. Diagnosis of children with specific language impairment using a developmental scale. Arq Neuro-Psiquiatr. 2004;62(3).

11. Wertzner HF, Amaro L, Teramoto SS. Gravidade do distútbio fonológico: julgamento perceptivo e porcentagem de consoantes corretas. Pró-Fono Revista Atualização Científica. 2005;17(2):185-94.

12. Barreto SS, Ortiz KZ. Influência da velocidade articulatória e da intensidade na inteligibilidade de fala. Pró-Fono Revista de Atualização Cientóífica. 2008;20(2):87-92.
13. Baken RJF, Orlikoff R. Speech movements: In: Clinical measurement of speech and voice. San Diego: Singular Thompson Learning ed.; 2000. p. 511-74.

14. Yaruss JS, Logan KJ. Evaluating rate, accuracy, and fluency of Young children's diadochokinetic productions: a preliminary envestigation. Journal of Fluency Disorders. 2002;27:65-86.

15. Ferreira-Jeronymo RR, Galera CA. A relação entre a memória fonológica e habilidade lingüística de crianças de 4 a 9 anos. Pró-Fono Revista de Atualização Cientóífica. 2000;12(2):55-60.

16. Shriberg LD, Kwiatkowski J: Phonological disorders III: a procedure for assessing severity of involviment. J Speech Hear Res. 1982;47:256-70.

17. Epstein CM, Meador KJ, Loring DW, Wrigth RJ, Weissman JD, Sheppard S, Lah JJ, Puhalovich F, Davey KR. Localization and chracterization of speech arrest during transcranial magnetic stimulation. Clin Neurophysiol. 1999;110:1073-9.

18. Wertzner HF, Herrero SF, Iderilha PN, Pires SCF. Classificação do distúrbio fonológico por meio de duas medidas de análise: porcentagem de consoantes corretas (PCC) e índice de ocorrência dos processos (PDI). Pró-Fono Revista de Atualização Cientóífica. 2001;13(1):90-7.

19. Wertzner HF. Estudo de acertos substituições e omissões em vocábulos inseridos em fala contínua. Pró-Fono Revista de Atualização Cientóífica. 1997;9(2):62-8.

20. Wertzner HF, Sotelo MB, Amaro L. Analysis of distortions in children with and without phonological disorders. Clinics. 2005;60(2):93-102.

21. Smith A. Speech motor development: integrating muscles, movements, and linguistc units. Journal of Communication Disorders. 2006;39:331-49.

22. Gross AM, Kellum GD, Hale ST, Messer SC, Benson BA, Sisakun SL, Bishop FW. Myofunctional and dentofacial relationship in second grade children. The Angle Orthodontist. 1989;60(4):247-53.

23. Clark HM, Robin DA, McCullagh G, Schmidt RA. Motor control in children and adults during a non-speech oral task. J Speech Lang Hear Res. 2001;44(5):1015-25. 
24. Hage SRV. Avaliação fonoaudiológica em crianças sem oralidade. In: Marchesan IQ, Zorzi JL. (orgs.). Tópicos em Fonoaudiologia, Rio de Janeiro: Revinter; 2003. p. 175-85.

25. Farias SR. Estudo da relação entre fala, tônus e praxia do sistema estomatognático em pré escolares. [tese] São Paulo (SP): Universidade Federal de São Paulo - Escola Paulista de Medicina; 2005.
26. Ziegler W. Psycholinguistic and motor theories of apraxia of Speech. Sem Speech Lang. 2002;23:231-43.

27. Paus T, Zijdenbos A, Worsley K, Collins DL, Blumenthal J, Giedd JN, Rapoport JL, Evans AC. Strutural maturation of neural pathways in children and adolescents: in vivo study. Science 1999; 283:1908-11. 